\title{
Europe, the British Empire and the Madeira Trade: Catholicism, Commerce and the Gordon of Letterfourie Network c.1730-c.1800
}

British merchants dominated the trade in wine from the Portuguese Atlantic island of Madeira in the eighteenth century. David Hancock has calculated that within their number, 29 per cent in 1768 were of Scottish origin. ${ }^{1}$ One such merchant house was that of the Gordons of Letterfourie in Banffshire. An examination of their business activities suggests a number of ways in which Madeira was a key node in a number of networks with significance for our understanding of the place of eighteenth century Scots in the construction of Britain and its Empire. Geographically, Madeira was an important crossroads in trade networks. In an era of sailing ships, the direction of prevailing winds made Madeira a natural and important stopping off place for ships heading from Britain to both the Americas and to India. Ships put in at Madeira to take on fresh provisions and to pick up Madeira wine. This geographical position also gave the island strategic importance to the Royal Navy. This was supported by the long history of political alliances between Britain and Portugal. ${ }^{2}$ Stemming from English alliances in the fourteenth century, treaties of 1654 and 1703 gave English, and later Scottish and Irish, merchants access to Portuguese markets. Portugal gained support in preserving her independence while the Royal Navy could access servicing ports on both the Iberian mainland and on Atlantic islands. In turn, Madeira came to occupy an important part in linking existing European patterns of trade with the new opportunities offered by the Americas and India. Given the historic orientation of Scottish trade to Scandinavia, the Baltic and the Netherlands, Scottish merchants were in a good position to draw on connections forged there. The experience of the Gordons of Letterfourie thus lends some support to the argument of Stephen Conway that we

\footnotetext{
${ }^{1}$ David Hancock, Oceans of Wine: Madeira and the Emergence of American Trade and Taste, (New Haven: CT, 2009), 138.

${ }^{2}$ L. M. E. Shaw, The Anglo-Portuguese Alliance and the English Merchants in Portugal 1654-1810, (Aldershot, 1998).
} 
need to balance a shift to the Atlantic with enduring connections to mainland Europe. ${ }^{3}$ However, Madeira also offers an opportunity to assess the ways in which Roman Catholics could carve out successful niches in a British project characterised that a national level by a commitment to Protestantism. ${ }^{4}$

The network operated by the Gordons, centred on Madeira, London and Banffshire, extended across the globe. India, the West Indies, North America and the Baltic were key nodes and they were connected by extensive correspondence. Through this correspondence relationships were developed, sustained and, at times, terminated. ${ }^{5} \mathrm{~A}$ small portion of this correspondence survives, scattered, like the network it created, in many places. The main collection is in the papers of the Gordons of Letterfourie, deposited in the library of the University of Aberdeen in 2010. ${ }^{6}$ Still uncatalogued at the time of writing, this collection has at its core a letter book of 1765 to 1775 containing copies of 778 letters sent from the London counting house to a range of destinations. Scattered throughout the collection's estate papers are further letters which shed light on mercantile activities. Other letters relating to these activities turn up in other archives. Valued for their early stamps rather than their contents, a cache of 98 letters, mainly to James Gordon at the

\footnotetext{
${ }^{3}$ Stephen Conway, Britain, Ireland, and Continental Europe in the Eighteenth Century: Similarities, Connections, Identities, (Oxford, 2011).

${ }^{4}$ Linda Colley, Britons: Forging the Nation 1707-1837, (New Haven, CT, 2005).

${ }^{5}$ Emma Rothschild, The Inner Life of Empires: An Eighteenth Century History, (Princeton, NJ, 2011).

${ }^{6}$ As the collection is uncatalogued, items are given in as much detail as possible within box numbers. Although the individual items are bundled, as yet no titles are attached to these bundles. Letters are therefore given with the correspondents, place and date within box numbers two, nine or ten. Another box labelled 'Tiger Duff' is also referred to. The letter book is referred to by that title. The collection is in the Special Collections Centre of the Library of the University of Aberdeen and special thanks are due to them for facilitating access.
} 
Jamaica Coffee House in London, survives in the British Postal Postal Archive in London. ${ }^{7}$ In the same city, the Senate Library of the University of London has a further eight documents. ${ }^{8}$ At the other end of the network, letters relating to dealings with the house can be found in the estate papers of, for example, the Duke of Gordon and Grant of Monymusk, both of north east Scotland. ${ }^{9}$ These sources, although fragmentary, enable us to recreate aspects of the house's activities. Financial records are missing, so it is not possible to quantify these aspects, but there is sufficient for us to get a sense of how they dealt with customers, suppliers and competitors, as well as the tensions inherent in family networks. The focus in this article is primarily on business activities, rather than the 'inner lives of Empire' that Emma Rothschild has explored in the case of another Scottish family, the Johnstones. This is because the surviving records are much fuller on such activities, although they do hint at other concerns.

We begin with an outline of Madeira as both a place and a product, before outlining the role of British merchants in the development of both. The introduction of James Gordon to the Madeira business in 1730 is set in the context of the Roman Catholic and Jacobite traditions of his family in north east Scotland. The implications of such traditions for economic activity are outlined in the broader context of Scottish economic development, especially mercantile networks, to that date. A broad outline of the development of trading networks is developed up to the point of the main focus of the article, the heyday of trading represented by the letter book in the 1760 s and 1770 s. The correspondence is analysed for details of customers, suppliers and competitors. This leads into a consideration of a major shift of focus in trading activities from the Atlantic to India, facilitated by participation of members of the family network in the British imperial project. The article concludes

\footnotetext{
${ }^{7}$ British Postal Archive, London, PH155, Sydney Turner collection, Letters addressed to James Gordon at London.

${ }^{8}$ Senate House Library, University of London, MS 754 Papers of the Gordon family.

${ }^{9}$ National Records of Scotland, Edinburgh, GD44 Duke of Gordon muniments GD44/43 Letters; GD345/943 Grant of Monymusk, Mr Jas Duff of Madeira \& his father Mr Duff of Pitchaish.
} 
by highlighting the need for further attention to trade with Portugal in general and Madeira in particular in shaping eighteenth century northern Scotland, particularly in the opportunities it supplied for Catholics to be involved in the construction of British trade and empire while drawing on existing links with Europe.

\section{Place and product}

The island of Madeira lies in the Atlantic Ocean 559 miles southwest of Lisbon. It was claimed by Portugal in 1425 and remained in its possession. The island is small - only 90 miles round - and mountainous. However, it is also extremely fertile and the Portuguese settlers began to develop this natural fertility, especially by channelling water from the rain swept north side of the island to the more sheltered south through an intricately engineered system of canals known as 'levadas'. This promoted the growth initially of sugar cane, but the development of the Caribbean islands in the slavery-based production of this crop meant a shift into the production of wine. Hancock gives an excellent and detailed account of the production of wine and its acquisition by merchants for export. One particular feature which had become common practice by the mid-eighteenth century was the addition of brandy to the blend of wine to enhance palatability. In addition, it was found that the heat and motion to which the wines were subject on their long voyages improved their quality. The island was ideally placed, because of the prevailing winds, for ships heading from Britain to the West Indies and North America, which became prime markets for the wine. Madeira gained a reputation as a premium product, keenly prized in aristocratic households. Its appeal spread, as we will see, in the development of broader consumption patterns that marked the eighteenth century, patterns that the Madeira merchants both encouraged and took advantage of. The details of how one firm tackled this demand will emerge later; for now, it is necessary to consider why Scottish merchants, in particular, might move into the trade.

Debate about the nature of the Scottish economy at the beginning of the eighteenth century continues, with the importance of merchant and shipping networks outwith the country being 
increasingly recognised. ${ }^{10}$ Rössner argues that it was not until thirty years after Union with England that Scotland felt the commercial benefits. He notes that

The wine trades had an age-old tradition in 1707 and were part of Scotland's continental link. Traffic in Spanish and Madeira wine, however, after 1707 became increasingly integrated into the triangular patterns of the Atlantic economy, connecting Scotland with the Iberian Peninsula, Madeira and the Canaries, the Caribbean and North America. ${ }^{11}$

This integration into broader patterns of trade facilitated by the Union is an important context for the activities of Gordon of Letterfourie. However we first need to understand the disabilities that the family laboured under by dint of their adherence to Roman Catholicism. Since 1560 Scotland had been the most thorough example of Reformed Protestantism in Europe. ${ }^{12}$ Its Presbyterian form of church government was confirmed by the Revolution settlement of $1690 .{ }^{13}$ It was marked by a bitter opposition to the Roman Catholic church and a desire to extirpate it from the whole country. However it persisted in some areas, notably in the glens of Banffshire where the Duke of Gordon retained territorial sway and a rather vacillating attachment to the faith of his fathers. Overlaid on this dangerous allegiance was another; that to the exiled Stuart kings. The expulsion of James VII and II from the throne first of England and then of Scotland by the invasion of William of Orange from

\footnotetext{
${ }^{10}$ Steve Murdoch, Network North: Scottish Kin, Commercial and Covert Associations in Northern Europe, (Leiden, 2006); Allan Macinnes, Union and Empire: The Making of the United Kingdom in 1707, (Cambridge, 2007).

${ }^{11}$ Philipp Rössner, Scottish Trade in the Wake of Union (1700-1760): The rise of a warehouse economy, (Stuttgart, 2008), 159.

12 Diarmaid MacCulloch, Reformation: Europe's House Divided 1490-1700, ( London, 2004), 378-82.

13 Jeffrey Stephen, Defending the Revolution: The Church of Scotland 1689-1716, (Farnham, 2013), 75.
} 
the Netherlands in 1688 created a new class of political opposition in Britain, the Jacobites. Amongst their number were the Gordons of Letterfourie. ${ }^{14}$

In 1689 John Gordon of Letterfourie was in Edinburgh Castle when it held out under the command of the Duke of Gordon for James against William's Scottish adherents. ${ }^{15}$ His son, James, supported the Rebellion of 1715 in support of the 'Old Pretender', that is, the son of James VII, and fought at the battle of Sherrifmuir. In turn his son, Alexander, fought in the next, and final, Jacobite rising of 1745 in the cause of Charles, grandson of James VII. He was at the bloody end to that campaign at the battle of Culloden as one of Charles' Lifeguards and fled into exile in France. This was a family, therefore, committed to the causes of both Roman Catholicism and Jacobitism, both of which put them at extreme disadvantage. They were able to cling to their estate which lay near the Banffshire coastal village of Buckie but only with a considerable struggle. Penal legislation against Roman Catholics by the Scottish Parliament in 1700 meant that they were prevented from registering title to land, so that when James sought a new charter in 1712 he was advised that it 'be granted to a protestant who may be a friend of James Gordon, which friend may grant bond to him for the Equivalent sowm [sum] he pays to the marquis for these lands' ${ }^{16}$ This might be an indication of a connection which was important for the later recovery of the family fortunes. Although there is no direct evidence to support it, the circumstantial evidence would point to this Protestant friend being Patrick Duff of Craigenoch. Although details for him are sparse, he was wealthy enough to figure in the list of creditors for Archibald Grant of Monymusk in 1732, holding a mortgage over his lands of

\footnotetext{
${ }^{14}$ Alistair Tayler and Henrietta Tayler, The Book of the Duffs, Volume 2, (Edinburgh: 1914), 203.

${ }^{15}$ Special Collections Centre, University of Aberdeen, MS3051/1/8/4 Papers of J M Bulloch relating to Gordons of Letterfourie

${ }^{16}$ Box 10 Memorandum for John Gordon 11 April 1712; James F. McMillan, 'Mission accomplished? The Catholic underground' in T. M. Devine and J. R. Young (eds), Eighteenth Century Scotland: New Perspectives, (East Linton, 1999), 93; Alan Macinnes, 'Catholic recusancy and the penal laws 1603-1707', Records of the Scottish Church History Society, 23, 1987, 27-63.
} 
Ballintomb, on Speyside. ${ }^{17}$ This relative affluence might explain the marriage of his son, John, to Mary Gordon in 1739. They were married in the parish church of the Church of Scotland in Rathven, confirming this unusual alliance between committed Roman Catholics and at least nominal Presbyterians. ${ }^{18}$ Their family will play an important role in the expansion of the House of Gordon, but first we need to understand more about the reasons why James Gordon entered the Madeira wine trade.

The career opportunities for Roman Catholics in Scotland were bleak, especially when they had a landed estate which they wished to preserve. Those with the martial traditions of the Letterfourie family were barred from service in the armed forces, a traditional outlet for the sons of the Scottish gentry. While members of the extended family were in positions in the Catholic church this meant moving abroad, typically to France, and then living a clandestine existence in Scotland. ${ }^{19}$ Trade was therefore one of the outlets available. As we have noted above, there was an existing Scottish wine trade, although this was stronger with France than with Iberia. 'At one time,' reports F. Marian McNeil, ' Scotland was reputed to drink more claret than any other country, and Edinburgh to have a more discriminating taste in that wine than any other city outside France. ${ }^{\prime 20}$ Against this was the encouragement given to the consumption of Portuguese wines following a number of treaties to encourage trade. Wines from Madeira and the Azores were, after the marriage of Catherine of Braganza to Charles II, exempted from the requirements of the Navigation Acts, which meant that goods to England and the colonies had to be carried in English ships. When enforcement of these

\footnotetext{
${ }^{17}$ Archibald Grant, A True and Exact Particular and Inventory of all and Singular the Lands, Tenements and Hereditaments, Goods, Chattels, Debts and Personal Estate Whatsoever, Which I Sir Archibald Grant,... was Seized or Possessed of or Intitled Unto in my Own Right, (London, 1732), 14.

${ }^{18}$ MS3051/1/8/4 Papers of J M Bulloch

${ }^{19}$ McMillan, 'Mission accomplished', 95-6.

${ }^{20}$ F. Marian McNeill, The Scots Cellar: Its Traditions and Lore, (Edinburgh, 1973), 33.
} 
regulations was tightened up by the English government, the carrying trade to and from Madeira remained exempt, something which aligned well with Scottish experience in expertise in tramp shipping (that is, picking up traffic from port to port, rather than sailing on defined routes with specific cargoes). ${ }^{21}$ Although the history of the consumption of Madeira in Scotland is not clear, by the second half of the seventeenth century Captain Robert Anderson of Glasgow was trading successfully with Spain and Portugal. ${ }^{22}$ His business moved to Lisbon in 1696, where he died in 1712. His business was carried on by the Maynes, linked by marriage, who became successful Lisbon merchants and important for the Gordons. ${ }^{23}$ This points to an important feature of Scotland; much of the economic success of its inhabitants was secured outwith its boundaries. ${ }^{24}$ In particular, there was extensive participation in mercantile networks in the Baltic, producing significant merchant communities in places such as Gothenburg, Sweden, Danzig, Poland and Riga, Latvia. ${ }^{25}$ These were joined to important religious links between the Presbyterians of Scotland and the Reformed Protestants of the Netherlands. ${ }^{26}$ These paralleled extensive Scottish attendance at Dutch universities, notably Leiden, and the importance of the Netherlands as Scotland's prime trading partner. ${ }^{27}$ These networks would be important for Scottish merchants in Madeira.

\footnotetext{
${ }^{21}$ Macinnes, Union and Empire, 159.

${ }^{22}$ Fenton notes that customs were levied on Madeira in Scotland in 1612: Alexander Fenton, The Food of the Scots, (Edinburgh, 2007), 90.

${ }^{23}$ David Chesnutt, The Papers of Henry Laurens: Sept. 11, 1746-Oct. 31, 1755, (Columbia, SC, 1968$), 64$.

${ }^{24}$ Murdoch, Network North, 5

${ }^{25}$ Alexia Grosjean and Steve Murdoch (eds), Scottish Communities Abroad in the Early Modern Period, (Leiden, 2005), 134.

${ }^{26}$ Ginny Gardner, The Scottish Exile Community in the Netherlands, 1660-1690, (East Linton, 2004), 118.

${ }^{27}$ Esther Mijers, 'Between empires and cultures: Scots in New Netherland and New York', Journal of Scottish Historical Studies, 33(2), (2013), 163-195.
} 
For James Gordon, however, it might have been London that was more significant as the initial impetus, with the Scottish connections outlined being more significant later in his mercantile career. James was the second son of James Gordon of Letterfourie. His elder brother, Patrick, died in 1737 so he would eventually succeed to the family estates, but this destiny was not clear when in 1730 he entered into the Madeira wine trade. He did so as he followed in the footsteps of other Scots heading south. Jerry White points to the success of the architect James Gibb, an Aberdeenshire Catholic, after his move to the capital of the newly united Britain in $1708 .{ }^{28}$ While still subject to civil restrictions, Catholics might be more easily able to find successful niches and a degree of relative anonymity in the bustling city of over 500,000 inhabitants. It was here that he entered business with William Halloran, a Galway merchant who appears to have shared Gordon's faith. Halloran had an established partnership with Manuel da Costa Campos of Madeira. He had accompanied Halloran to the island, where they found that Halloran's attempts to solicit business in London had not been matched by comparable exertions on the island. Halloran returned to London after four months, entrusting Gordon with the task of sorting out the business on the island. On Gordon's subsequent account 'tho' young \& of course of small experience in ye world, [he] yet resolved to answer $\mathrm{Mr}$ Hallorans hopes as far as lay in his power, and accordingly apply'd to learning ye language \& manners of the people, which he came to know in about two years time as well as could be expected'. ${ }^{29}$ He found the situation worse than they had feared and worked to extricate Halloran from the partnership, which was achieved by 1734 . From this point Gordon acted in partnership with Halloran until the latter's death in 1758. At some point, exactly when is not clear, his brother Alexander must have made his way to the island from exile in France. Their position as Catholics might have helped them settle into island life, given the devout adherence on the island to that faith. In 1760 James returned to London leaving Alexander to run matters on the island; from this point the house is known as James and Alexander Gordon, suggesting a new partnership, albeit one

\footnotetext{
${ }^{28}$ Jerry White, London in the Eighteenth Century: A Great and Monstrous Thing, (London 2012), 17.

${ }^{29}$ Box 10, State of the case betwixt the late Mr Wm Halloran of London \& his partner Jas Gordon of Madeira.
} 
in which James was the prime mover. Another significant event was the arrival in 1761 of James Duff, the eldest son of their sister Mary. After a period of training he was able to take over the management of affairs on the island, supported by his younger brother Robert, who arrived on the island in 1767 . With two trusted family members on the island, Alexander returned to London in 1769, at which point James Duff was made a partner. For two years Alexander conducted most of the business in London, but in 1771 he returned to Scotland, where he bought a small estate as well as running his brother's inherited estate at Letterfourie. By 1775 Robert was also accepted into partnership, so at the time of the letter book the shape of the mature partnership was established James soliciting business in London, Alexander attending to matters in Scotland and the Duff brothers running affairs in Madeira. This is the context for examining what their letters tell us about customers, suppliers and competitors in the Madeira wine trade in the third quarter of the eighteenth century.

\section{Customers, suppliers, competitors}

A high proportion of the letters recorded in the letter book, 45 per cent, were internal ones between the London partners and their island managers. Aspects of the market strategy of the house can be gleaned from their contents, but there are also letters to customers which indicate where it placed its efforts. They indicate two major markets, Britain and the West Indies, and distinct strategies within each. Hancock has argued that, 'founding partners of Madeira's wine houses began by appealing to personal contacts: to their families and to the patronage and peer groups from which they had come. Almost always, these groups were based on shared ethnic or religious background'. ${ }^{30}$ This is borne out by the Gordon letter book, but this also indicates development over time. A central principle for the Gordons was that they would not sell on their own account, nor would they engage in speculative 'adventures'. 'We are not at all in the wine trade here, nor did we ever import any for

\footnotetext{
${ }^{30}$ Hancock, Oceans of Wine, 145.
} 
sale,' James Gordon informed a prospective customer in $1772 .{ }^{31}$ He advised one of his long term suppliers in Hamburg who was thinking of obtaining a return cargo of Madeira for sale in London that 'I think Madeira is generally an unprofitable Speculation to this Place, \& fear you will get nothing, but rather loss, by your small Concern it, tho' I wish the contrary' ${ }^{32}$ Writing to his nephew in Madeira, James commented that 'I think the whole business is like to turn into Particular Orders, at least they will be the most material Part of it, and we must look after them' ${ }^{\prime 3}$ By this he meant orders which he had directly solicited for specific customers. This continued trends which had been consolidated since he had returned to London, and which turned on two groups of customers: wealthy individuals and London wine merchants.

Although the records of the business before 1761 are missing, it does seem reasonable, based on the continuing business after that date, to assume that Gordon had worked his network of Scottish aristocratic contacts, something which would be assisted by his own landed background. Thus, the Duke of Gordon was a customer, as was the Earl of Fife, both of the leading territorial magnates in the north east. In 1767, for example, following a visit to Scotland, James ordered a hogshead of wine each for Sir Robert Abercromby of Birkenbog, General Abercromby and William Urquhart of Craigston, all local landowners. 'Let the wine be the best,' he cautioned, 'or I can never show my face in the Country. ${ }^{34}$ Comments like this suggest that Gordon was aiming for a premium niche in the market, aware perhaps that he could not rival the efforts of competitors in other markets (of which more below). The aim of expanding the customer base was clearly a key part of his return to London in 1761. As his brother wrote to him from Madeira

\footnotetext{
${ }^{31}$ Letter book, James Gordon (JG), London to John Fern, Lichfield, 28 April 1772.

32 Letter book, JG, London, to Klefker and Paschen, Hamburg, 28 June 1771.

${ }^{33}$ Letter book, JG, London, to James Duff, Madeira, 21 October 1771.

${ }^{34}$ Letter book, JG, London to Alexander Gordon (AG), Madeira, 1 January 1767.
} 
As to particular wines, tho many people may decline ordering them on acct of the high price, others must have them Cost what they will, I need not suggest to you the means of obtaining a share of such orders from England, perhaps an acquaintance and friendship with some Gentn of fortune and influence in the other end of town may be in no bad way. ${ }^{35}$

James was not keen on his new role, finding the busyness of London disconcerting. His letters complain of being in competition with 'so many Buzzers \& Sollicitors' ${ }^{36}$ Knowing his brother's rather reserved disposition, Alexander sought to encourage him: 'With the short acquaintance you must as yet have of London, and the few connections you can hitherto have made tis no wonder others should have the advantage of you, yet I think, judging from what you have been able to do in so bad a year, and in the Beginning of your Solicitations, there is no room to despond'. ${ }^{37}$ Nevertheless, James' efforts appear to have borne fruit. The first set of customers in 1763 give a good indication of who was being aimed at. ${ }^{38}$ Wine was ordered for Henry Drummond Esq, Richard Bull Esq, Sir Robert Smyth Bart and Humphrey Morris Esq. The first two were to become Members of Parliament, the first with Scottish connections. ${ }^{39}$ Drummond was a wealthy banker whose father had been executed for his part in the 1745 Rising. When he entered Parliament in 1774, it was as a supporter of Lord North. Bull was the son of a wealthy merchant and a demanding customer. Clearly a repeat customer, James Gordon was worried in 1774 'that Mr Bull's pipe sounds as if it were half leaked out, which is the Devil, I do not in the least blame you for it, tho' must tell you of it, Mr Bull is a Gentn of fortune \& a Member of Parliam[en]t, \& I shall have an ugly piece of work about it, as there

\footnotetext{
${ }^{35}$ Box 9, AG Madeira to JG, London, 18 August 1761.

${ }^{36}$ Letter book, JG London to AG, Madeira, 20 March 1768.

${ }^{37}$ Box 9, AG Madeira to JG, London, 18 August 1761.

${ }^{38}$ Box 9, despatch notes, 19 April 1763.

39 'Bull, Richard' and 'Drummond, Henry', History of Parliament Online, http://www.historyofparliamentonline.org/volume/1754-1790/, [accessed 28 May 2014].
} 
is no persuading such people that we are free from blame'.${ }^{40}$ Smyth had a country estate in Farnham, Suffolk; it has not been possible to establish the identity of Morris. ${ }^{41}$

These orders also indicate something of the variety of products and delivery mechanisms. All of the orders were to be in casks made of staves sourced from Hamburg rather than America. Leakage was a persistent worry and the Hamburg staves were felt to be of higher quality, with clear implications for supply routes. These orders were all to go round via the West Indies. As Gordon explained to a prospective customer, Lady Davers of Bury St Edmunds, not only were there very few ships returning direct to London from Madeira, but also 'by which progress they say it is greatly improved' ${ }^{42}$ The wine would be shipped to her at her own risk to be paid for by a bill due thirty days after it was presented to her which would be drawn after the bill of lading was produced - meaning that customers paid for their wine before it arrived. He suggested to another customer, Ralph Carr of Newcastle, that 'Sea Hazard from Bbdos to London of a fine River built ship in the height of Summer I look upon to be very little. ${ }^{\prime 43}$ Because of this, he suggested, most customers did not take out insurance. Three of the 1763 customers ordered old wine, but that for Henry Drummond was to rest for two years in Barbados. All of them ordered a pipe of wine, holding (usually) 110 gallons. They were all charged $f 29$ 10s a pipe for old wine, so these were significant purchases.

The quality of the wine seemed to outweigh the risks concomitant on this process. The letter book records 61 individual customers across the country to whom bills were presented. Of course, the many London customers would not show up in such a count, given the possibility of the personal presentation of bills, but the success of Gordon's targeted marketing can be seen in the letters. He was working his personal contacts. Ordering in 1766 a hogshead for Lord Oliphant, a Scot returned

\footnotetext{
${ }^{40}$ Letter book, JG London to James Duff, Madeira, 12 October 1774.

${ }^{41}$ William Betham, Baronetage of England, Volume 3, (London, 1803), 182.

42 JG, London to Lady Davers, Bury St Edmunds, 9 June 1772.

${ }^{43}$ Letter book, JG London to Raplh Carr, Newcastle, 13 July 1773.
} 
from estate management in Jamaica and resident on Great Pulteney Street in London, he urged 'this is a Worthy honest Gentn with whom I dine almost every Sunday, let me not be put to the Blush for the Wine \& be oblig'd to desert his hospitable House' ${ }^{44}$ In the following year another Scot in London, Adam Drummond, MP, ordered a pipe..$^{45}$ In 1770 he drew attention to a particular order: 'there is one pipe for Lord North's Secretary which must be Superlatively good, it is so recommended in order to give us a name in that end of the Town' ${ }^{46}$ This injunction must have been followed, for in the following year there was an order for Lord North himself, Prime Minister from 1770 to $1782 .{ }^{47}$ This was a significant order, for soon after there was another of five pipes for the Duke of Portland, 'who I suppose intends part of them for some others of the Nobility his friends. They are to lay at least 12 Months in Grenada, \& if their Quality is approved of, I am told (Can't say if it will happen so) large Orders will be the Consequence' ${ }^{48}$

This part of the strategy, therefore, seems to have paid off. It was accompanied by a complementary focus on supply to wine merchants and taverns, again with quality in mind. The main customer here was the Metholds, wine merchants of Fenchurch Street. They first appeared as customers in 1761, when they ordered 15 butts (which seems to be used interchangeably with a pipe as a measure, although often filled to 120 rather than 110 gallons). ${ }^{49}$ They were, said Gordon in 1773 , 'good men, tho' hard, but sure pay'. ${ }^{50}$ Despite occasional disputes, they were regular customers, with orders up to fifteen butts at a time. In 1770 he was delighted to hear from them that the wine they had

\footnotetext{
${ }^{44}$ Letter book, JG London to AG Madeira, 28 January 1766.

45 Letter Book, JG London to AG Madeira, 7 February 1767.

${ }^{46}$ Letter book, AG London to James Duff Madeira, 8 March 1770.

${ }^{47}$ Letter book, JG London to James Duff Madeira, 30 October 1771.

${ }^{48}$ Letter book, JG London to James Duff Madeira, 6 November 1771.

${ }^{49}$ Box 9, AG Madeira to JG London, 12 April 1761

${ }^{50}$ Letter book, JG London to James Duff Madeira, 6 January 1773.
} 
supplied from him to the London Tavern was better than that of Newton, a key competitor. ${ }^{51}$ "I do assure you," wrote James to his brother in 1769, 'that your frd Newton is using the strangest arts that can be devised by the heart of Man to undermine me with those people [presumably the Metholds] I know what he has done, better than he is aware of, but more of this in future' ${ }^{52}$ The London Tavern rebuilt in 1765, was the premier meeting place in London. 'There is just finished ye most Sumptuous Tavern ever seen in London,' wrote James in 1768, '... the trade of it will be immense if once acquires a fame for Good Wines'. ${ }^{53}$ He sought to obtain orders from this growing network of taverns catering for an expanding middle class market. ${ }^{54}$ Consistent with the focus on the premium market, he secured an order in 1773 for a pipe for the St James Coffee House, which was, 'resorted to by many of the Nobility of the Court, \& Officers of the Guards, \& if the wine is liked, this order will in all probability be productive of your shipping many more Pipes' ${ }^{\prime}{ }^{5}$

The other leg of business was the Atlantic trade. While Hancock focuses on British North America, for the Gordons the key market seems to have been the West Indies. In the letter book there were 46 letters to destinations in the West Indies, compared to nineteen to British North America. Within the West Indies the dominant destination was Grenada, with 27 letters, reflecting in turn the influx of Scots to that island following its capture from the French in 1762. Numbers of Scots passed through Madeira carrying recommendations from James Gordon for hospitality on the island. One was his cousin William Dunbar, going to assist in the management of the estate of De Ponthieu and he became a frequent correspondent. ${ }^{56}$ Another was Roderick Williamson, who took 20 butts of

\footnotetext{
${ }^{51}$ Letter book, AG London to James Duff Madeira, 27 February 1770.

52 Letter book, JG London to AG Madeira, 16 October 1769.

${ }^{53}$ Letter book, JG London to AG Madeira, 25 February 1768.

${ }^{54}$ Rudé, Hanoverian London, 70.

${ }^{55}$ Letter book, JG London to James Duff Madeira, 29 March 1773.

${ }^{56}$ Letter book, JG London to James Duff Madeira, 9 December 1771.
} 
wine, sent in quarterly loads, from $1770 .{ }^{57}$ Writing to John Reid in Jamaica, Gordon advised this method of splitting orders. Their payment arrangements were generally to draw bills at dates ranging from 30 to 90 days sight. In this case he 'having a friend in London that would always be ready to honour our drafts, accmpd with Bills of Lading \& Inv of the Wines Shipped him, \& to make things as easy \& convenient as possible we shall be willing to draw at six or even eight months sight for the first year at least'.$^{58}$ The problem with such customers, however, was securing payment. By 1775 Williamson owed over $£ 1200 .{ }^{59}$ Similar problems led Gordon to despair

I would have you totally to drop Consigning Wine \& West India Schemes on the Houses acct. I shall never more encourage one pipe that way, nothing but destruction can follow it, I have not the Scrape of a Pen from St Christrs, Antigua or Jamaica, \& as for the last of these Places, my real opinion is that the Merchts we meet with here, whom we deem by all appearances men of honor \& honesty, \& such as may be rely'd on for Punctuality, Lose all sense of either after they get to that Isld, \& so universal is this Contagion amongst them, that I can except no one of those I ever made tryal of, for they think no more of remitting for a Consignment from Mada, or a Madeira debt, than of ye world to come, wch never enters into their heads. ${ }^{60}$

Despite observing of Jamaica merchants that 'they are all $\mathrm{R}$ Is and 'tis Ruin to have any concern with them', the house continued to trade to the West Indies, sending 70 pipes to Jamaica in $1771 .{ }^{61}$

\footnotetext{
${ }^{57}$ Letter book, AG London to James Duff Madeira, 21 May 1770.

${ }^{58}$ Letter book, AG London to John Reid, Jamaica, 4 January 1770.

${ }^{59}$ Letter book, JG London to Roderick Williamson, Grenada, 5 April 1775.

${ }^{60}$ Letter book, JG London to AG Madeira, 30 April 1768.

${ }^{61}$ Letter book, JG London to AG Madeira, 25 January 1768; Box 10, James Duff, Madeira to unknown correspondent (presumed JG in London) undated but from internal evidence April 1771.
} 
The other major market for Madeira was India, but here the brothers faced a problem. As James explained in 1766, captains, who could take a certain amount of cargo to sell on their own account, were obliged to take their business from those with influence with the directors of the East India Company:

The Ruling men of the Board of Directors making a point when they give them that voyage, that they shall do their Business with the House whose Principals here serve their Interest most, by holding a great deal of India Stock, which they split to make Votes at the Genl Yearly Election, in order to keep at the Board such as bring Grist to their Mill for the sake of their Votes. ${ }^{62}$

Occasional successes were scored; in the following years he secured an order from Captain Mills of the Kent for 50 pipes. This led to complementary orders from the first, second and third mates, the purser and the surgeon. Even the surgeon's mate took a pipe, with total orders amounting to some 90 pipes. ${ }^{63}$ But this was a rare success and James colourfully expostulated in 1772 , 'I could not go a greater length in bringing to those India Folks than I did, except for I had kisst their A_se'. ${ }^{64}$ As a strategy, that was less effective than purchasing stock. 'Neither my Bro or myself are proprietors,' lamented James to James Duff in 1772, 'but wish both we \& you too were, if money could be spared'. 65

That position was to alter later, but for now our attention turns to the suppliers. These fell into two categories: those who supplied the wherewithal to trade in wine, and those who were involved in the supply of goods for trade. The latter were, as we will see, of considerable importance, for effective participation in the Madeira wine trade was about much more than wine. The letter books

\footnotetext{
62 Letter book, JG London to AG Madeira, 10 May 1766.

63 Letter book, JG London to AG Madeira, 15 October 1767; 4 December 1767.

${ }^{64}$ Letter book, JG London to James Duff Madeira, 30 November 1772.

${ }^{65}$ Letter book, JG London to James Duff Madeira, 29 August 1772.
} 
are of much more assistance for external suppliers than for the local island vineyard owners, who only feature as ghostly figures in the background of activities. We have noted already the preference of the house for staves from Hamburg; they also needed iron hoops to secure the pipes, which were generally constructed on the island. An alternative was to have casks made up in England and freighted out with commodities such as flax or wheat. ${ }^{66}$ This points to the importance of trade in a range of commodities. As Alexander pointed out in 1763, 'We must watch all oppo[rtunitie]s of making something by Imports for I'm afraid our exports without this will make but a poor Figure'. ${ }^{67}$ The challenge was the small size of the market for goods against which to set the cost of high value wines, for 'there is no knowing what to send or avoid sending to your trifling market, which today is in want \& tomorrow is glutted by the smallest supply'. ${ }^{68}$ In addition to this, restrictions were placed by the government on what might be imported, restrictions which were perceived by merchants to be arbitrary and unpredictable. Such factors gave rise to considerable uncertainty, raising the value of information. The letter books give a useful indication of the major ports (five or more letters over the period) with which the house dealt, an indication which is supplemented by the letters preserved in the postal archive (table 1). (Lisbon will be considered separately)

Table 1: correspondence with ports. Source: calculated from letter book and letters in British Postal Archive

\begin{tabular}{|l|r|r|}
\hline Port & $\begin{array}{r}\text { Letter } \\
\text { book }\end{array}$ & $\begin{array}{r}\text { Postal } \\
\text { archive }\end{array}$ \\
\hline Amsterdam & 12 & 17 \\
\hline Bristol & 22 & 1 \\
\hline Cork & 14 & \\
\hline Danzig & 10 & 4 \\
\hline
\end{tabular}

${ }^{66}$ Box 9, AG Madeira to JG London, 29 February 1764.

${ }^{67}$ Box 10, AG Madeira to JG London, 12 February 1763.

${ }^{68}$ Letter book, JG London to James Duff Madeira, 6 April 1773. 


\begin{tabular}{|l|r|r|}
\hline Dundee & 22 & \\
\hline Falmouth & 5 & \\
\hline Gothenburg & 23 & 6 \\
\hline Hamburg & 15 & 13 \\
\hline Hull & 6 & \\
\hline Leith & 6 & \\
\hline Total & 135 & 41 \\
\hline
\end{tabular}

Three major commodities are indicated by this pattern: grain from Poland, exported via Danzig; herrings from Gothenburg; and Irish provisions via Cork. One voyage in 1766 indicates how trade with the Baltic built on existing Scottish shipping and mercantile networks. George Bellenden, who had worked as a surgeon for the East India Company before joining the extensive community of Scottish merchants in Gothenburg, became one of the major merchants in the port, trading extensively in timber. ${ }^{69}$ In July 1766 James Gordon ordered a cargo of 500 barrels of herrings. ${ }^{70}$ Herring were a sought after commodity at the island, provided that they arrived in August or September, 'as from that time their consumption begins, which lasts for some months'. ${ }^{71}$ Gordon contracted with the ship-owner John Rankin of Dundee for the vessel Fame under Captain Thornton to pick up this cargo. In parallel, he ordered six tons of raw flax from Lorentz Brockhusen of Riga to

\footnotetext{
${ }^{69}$ Anders Svensson, 'British merchant and tradesmen in the 1700 s Gothenburg', Traders and trading in the 1700s Gothenburg,
}

http://blog.zaramis.se/2011/12/28/brittiska-handelshus-och-handelsman-i-1700-talets-goteborg/ [accessed 6 June 2014].

\footnotetext{
${ }^{70}$ Letter book, JG London to George Bellenden, Gothenburg, 8 July 1766.

${ }^{71}$ Letter book, JG London to Scott \& Fraser, Gothenburg, 13 April 1773.
} 
be shipped to Gothenburg. ${ }^{72}$ This was to be supplemented by 100 bars of Swedish iron, another industry in which Scots had played a major role. ${ }^{73}$ When the flax arrived from Riga one bale got wet, so the rest were sent on, 'as we hope he will be the first ship to Madeira he being the first cleared out for that Island and indeed we know of none else'. ${ }^{74}$ Gordon was pleased to report that Thornton got his herring first to market before a glut. ${ }^{75}$ They were not so fortunate in other years, but the relationship continued until Bellenden's death in 1770, when the business transferred to another Scottish expatriate firm, that of Scott and Fraser. They also supplied French brandy to be added to the wine in preference to 'the harsh firey Brandy of the IsId' ${ }^{76}$ However, its import was strictly forbidden, so ways had to be found to get it past customs inspection.

I must also particularly advert to you to cause plaister the Heads \& Chines of the Pipes all over that they may pass for Pipes of Sweet Oil, such as no doubt you have seen imported at your place from Spain, this is intended for the greater facility of Introduction at Mada where Brandy is prohibited. ${ }^{77}$

Dealings with Gothenburg were consistent throughout the period, whereas the choice of supplier for wheat, another key commodity, depended on price differences between the Baltic and North America. For several years the house dealt with Trevor Corry \& Co in the port of Danzig (modern Gdansk) where names such as Stary Szkoty (Old Scotland) bear witness to long established Scottish merchant involvement. ${ }^{78}$ Corry, the British consul, was from a Northern Ireland family descended

\footnotetext{
72 Letter book, JG London to Lorenz Brockhusen, Riga, 7 July 1766.

73 Murdoch, Network North, 203.

${ }^{74}$ Box 10 George Bellenden, Gothenburg to JG London, 8 November 1766.

${ }^{75}$ Letter book, JG London to George Bellenden, Gothenburg, 7 April 1767.

${ }^{76}$ Letter book, JG London to John Rankin, Dundee, 18 October 1774.

${ }^{77}$ Letter book, JG London to Scott \& Fraser, Gothenburg, 18 November 1773.

${ }^{78}$ Devine, Scotland's Empire, 10.
} 
from Scottish emigrants. Cargoes of wheat were obtained from him between 1768 and 1770, but in 1771 supplies were switched to North America - New York in 1772, Quebec in 1773 - because of lower prices and a glut on the island. The other major commodity import was of provisions - butter, beef and candles - out of Cork. In addition to these commodities, the house also traded in dry goods. There were two groups of customers for these. In some cases they were for Madeiran individuals who they dealt with. So in 1773 James complained that sofas for 'Amto Joao', 'cost extravagantly high, they are large bulky uncommon things, \& even the Fr[eigh]t amo[un]ts to a great deal of money'. ${ }^{79}$ In other cases they supplied local shopkeepers with fabrics and clothing from both Britain and, more significantly, from Hamburg. Thus the Hamburg firm of Klefeker \& Paschen supplied not only staves, but also a range of textiles. In 1770, for example, as well as 1200 staves they shipped a barrel of starch and five chests containing textile goods ranging from table cloths to pieces of velvet. $^{80}$

All this trade required intermediaries to handle currency exchanges. The Amsterdam firm of Muilman was engaged to provide this service for Northern European destinations. Much the greatest letter traffic, however, was with Lisbon. 65 letters from the letter book and 45 from the postal archive were directed to this source, chiefly to the merchant house of Mayne \& Co. There was a connection here to Captain Anderson, who we met as a pioneer of trade between Scotland and Iberia. His sister married a member of the Mayne family, and it was his nephew Edward Mayne who took over his Lisbon business on his death in 1712. His descendant, William, returned to London in 1757 to run a banking business with his brother Robert. He and his brother both entered Parliament and William was raised to the Irish peerage as Lord Newhaven in $1776 .{ }^{81}$ They transacted Portuguese

\footnotetext{
${ }^{79}$ Letter book, JG London to James Duff, Madeira, 21 January 1773.

${ }^{80}$ Senate House Library 754/5, Klefker and Paschen, Hamburg 26 October 1770, Invoice of several goods, Shipt by the English Snow the Hamburg Packet Capn Geo Geary, by order of Mr Alexander Gordon \& compt at Madeira

${ }^{81}$ Chesnutt, Papers of Henry Laurens, 64.
} 
currency for the Gordons until a disagreement over a wine order in 1773 caused the Gordons, with some difficulty, to engage James Montgomery of Lisbon, son of an Irish politician to transact their business. $^{82}$

Their difficulty in finding a new agent was that Montgomery was already aligned with Newton and Gordon, and they were reluctant, for reasons of confidentiality, to share facilities. While Scots abroad were often seen as clannish, not all was amity. James Gordon recognised the preeminent position of Newton and Gordon, although always on the lookout for minor victories, as we have seen. Francis Newton was from a Jacobite background and so might have been expected to be on good terms with Alexander in particular, but a letter from Alexander in London in 1770 suggests that they fell out over words said in the heat of an argument. ${ }^{83}$ Earlier insinuations about 'false brothers' when Francis was in Madeira might suggest some of the suspicion that peppers the letters, with their frequent concerns about Newton poaching customers. ${ }^{84} \mathrm{~A}$ rather more friendly relationship subsisted with the firm of Scott, Pringle and Cheap, another Scottish house. James returned to London with John Pringle in 1760 and there was a continuing friendly tone about the competition between the two houses. Recognising that Cheap would prevent captains with who he had contracted trading with other houses, as he would do himself, James noted in 1775 that, 'the same friendship \& intimacy betwixt the Principals of that House \& me here still cordially subsists as heretofore' ${ }^{85}$ The other Scottish house to warrant mention was Ferguson, Murdoch \& Co, which got into severe financial trouble in 1772 . This led James to some financial strain of his own, as he supplied Murdoch with cash to help him over their troubles ${ }^{86}$ It is noticeable that only Scottish houses receive detailed mentions, although James was on occasion disparaging about other upstart

\footnotetext{
82 Letter book, JG London to James Duff, Madeira, 8 March 1773

${ }^{83}$ Letter book, AG London to James Duff, Madeira, 27 February 1770.

${ }^{84}$ Box 9 AG Madeira to JG London, 21 November 1762.

${ }^{85}$ Letter book, JG London to James Duff, Madeira, 4 March 1775.

${ }^{86}$ Letter book, JG London to William Dunbar, Grenada, 8 September 1772.
} 
houses and their potential to destabilise existing practices. There appears to have been a mirror community of Madeira merchants in London reflecting the shared interests of British merchants on the island. 'You have neighbours watchfull \& ready to hook every thing their own way,' James warned his nephew in 1772. 'It is the same with us all here, tho' we keep very fair with each other'.

${ }^{87}$ What this piece of advice reminds us of was the importance of family relationships in sustaining a network of trust across the markets in which the house operated. The presence of James and Robert Duff on the island allowed the Gordon brothers to return to Britain. In practice, it was James Gordon who ran affairs in London, soliciting orders and chasing payments. Alexander much preferred the life of a Scottish country gentleman, improving his brother's estate at Letterfourie (including the supervision of the building of a fine mansion house designed by Robert Adam) and purchasing a small estate of his own at Cairnbanno, Aberdeenshire, in 1772. However, it was another member of the Duff family, Patrick, who was to be of importance in the direction of the house after this point.

\section{The turn to the east}

Patrick Duff entered military service in India in 1760, seeing service at the battle of Buxar. He transferred to the artillery of the East India Company and, despite some ups and downs in his career (notably involvement in a mutiny of European officers in 1766), he progressed up the ranks, eventually reaching the rank of Major General in $1796 .^{88}$ His brothers, John and William, also saw service in the East India Company. The fate of another brother, Archie, who drove his uncle James to distraction, is not clear, although he appears to have gone to the West Indies. ('I'm terrified \& perplexed,' he wrote to his brother in 1779, 'with the thoughts of Archy Duff's coming again upon me, what in the name of Jesus must be done with him?'). ${ }^{89}$ It was James who looked after a succession of Duff boys on their way through London, attending to the completion of their education

\footnotetext{
${ }^{87}$ Letter book, JG London to James Duff, Madeira, 1 October 1772.

${ }^{88}$ Tayler and Tayler, Duffs, 466-490.

${ }^{89}$ Box 9, JG London to AG, Letterfourie, 20 September 1779.
} 
and kitting them out for their voyages. Patrick's acquisition of a fortune in India, principally through his command of the artillery of the Nawab of Oudh, paid off the debts incurred in this way. It also offered a powerful connection for the development of the house's trade with India, which became more important in the late 1770 s.

In 1777 James Gordon wrote to the steward of the Duke of Gordon, James Ross, expressing his regret at the loss of a butt of old Madeira. It survived one shipwreck on the voyage to Jamaica when it was rescued, but the vessel bound for Dundee was captured by a 'rebel privateer' and carried into New England. Gordon was furious that 'the Rebel Rascals of America should have got it', as well as some preserved lemons and a cask of sweet Malmsy intended as presents for the Duchess..$^{90}$ Although trade with North America clearly continued, as evidenced by a settlement of an invoice for $£ 2,699$ by Messrs Loring \& Winslow of New York, 'agents to General Sir William Howe', in 1779 for wines shipped in 1777 and 1778, the American War of Independence was a severe disruption to the Madeira trade, and not just to North America. ${ }^{91}$ The trade there, as Hancock explores in some detail, never recovered and forced Madeira houses to look elsewhere..$^{92}$ At the same time, the restrictions on trade with India were gradually being eased, making this lucrative market seem more tempting. It was in these circumstances that Patrick Duff proved to be a valuable asset.

Patrick's involvement in the Madeira wine trade appears to have begun in 1783, when he had ordered wine to the value of a thousand pounds to be divided amongst his friends. This was of high quality, better, in Patrick's estimation, than that which was supplied by the Company and 'Could I depend upon remittances, I could dispose of any Quantity of Wine, but that is not the case, and I am

\footnotetext{
90 NRS, GD44/43/ 185/20, James Gordon, London, 22 July 1777 to James Ross, Gordon Castle.

${ }^{91}$ Box 10, Statement, Messrs Loring \& Winslow of New York, agents to General Sir William Howe, 1779.

92 Hancock, Oceans of Wine, 120.
} 
not a Man of Business' ${ }^{93}$ Accordingly, he suggested a business relationship with a Scottish merchant in Calcutta, Alexander Colvin. For commission of $2 \frac{1}{2}$ per cent Colvin would dispose of the wine and acquire Bengal piece goods for the return voyage. Patrick would be able to undertake quality assurance, in particular affirming the quality of casks and the degree of any claimed leakage. In October 1785 he examined the wine after it had been landed and declared that 'it is allowed to be the best that ever was in this Country, and I am certain it is really so, and I am in great hopes it may be the means of introducing your House to more of the India business' ${ }^{94}$ He continued to solicit other customers, in 1787 reporting of one venture that 'Your wine bears the best character of any that has been sent to India, \& if this plan succeeds it will be confirming that character' ${ }^{95}$ Patrick returned to Scotland to inspect his newly purchased Banffshire estate in the following year, but returned to India in 1790. In the same year his uncle James Gordon died at Letterfourie and to a large extent the evidence dries up.

In 1801, by now settled in Scotland, Patrick reported gloomily that his brother James had failed financially, leaving him exposed. Not only had Patrick been involved to the extent of $£ 4,000$ in James' ventures, but his brother had also used $£ 9,000$ which had been entrusted to the pair for the upkeep of four orphan children from India. 'He has been extremely imprudent,' bemoaned Patrick, ' and in hopes of retrieving his losses at Lloyd's Coffee House he has run risques no wise man would do, and instead of getting better, it was, as the saying is, the longer the worse'.${ }^{96} \mathrm{He}$ also, thought Patrick, owed $£ 3,000$ to the Madeira house which was thereby also put at risk. His mercantile contemporaries, reports Hancock, also took a dim view of James' speculations, finding them 'solely

\footnotetext{
${ }^{93}$ Tiger Duff box, Bundle 2, Patrick Duff, Fort William to James Gordon, Letterfourie, 16 March 1784.

94 Tiger Duff box, bundle 2, Patrick Duff, Bengal to James Duff, London, 15 September 1785.

95 Tiger Duff box, bundle 3, Patrick Duff, Cawnpore to James Duff, London, 12 August 1787.

96 Tayler and Tayler, Duffs, 488.
} 
owing to his extensive and very imprudent engagements as an insurer, which is a vile gambling trade' ${ }^{97}$ However, correspondence between Robert, as a representative of the Madeira business, and the executors of Alexander Gordon (who had died in 1797) paints a more complex picture. James had been driven to reckless speculation, he argued, because of his uncle Alexander's demands for money. Alexander, he argued, was of a 'very adventurous \& speculative disposition', which had taken some time to recover from. ${ }^{98}$ Meanwhile, they had been paying off significant sums to both James and Alexander. Their efforts would have succeeded, he argued,

had not that Gentleman contrast to the Spirit of the agreement enter'd into, rigidly pressed for \& insisted on heavy payments at the most inconvenient Seasons, by which the House was cramped in many beneficial operations, that would have put it so much at ease that no claim of this nature would have existed, nor would Jas Duff have had any temptation for entering into the hazardous business that has proved so unfortunate to him \& to the House. ${ }^{99}$

It is, of course, impossible to determine whether this was simply special pleading or a reasonable account. Certainly, the letters hint at considerable differences between James Gordon, who seems to have been extremely cautious and methodical in his business dealings, and Alexander, who seems to have always had his mind on landed pursuits. Having purchased his own estate at Cairnbanno in 1772 , he set to rearranging leases and rentals, as well as levelling fields on the home farm. ${ }^{100}$ Alongside this, he continued an extensive programme of moorland reclamation at Letterfourie in addition to issuing new terms and conditions to tenants. ${ }^{101}$ His eye was always on the acquisition of new lands to enhance Letterfourie, being prepared to sell Cairnbanno in 1783 to acquire adjacent

\footnotetext{
${ }^{97}$ Hancock, Oceans of Wine, 161, citing Newton \& Gordon to Robert Lenox, February 21802.

${ }^{98}$ Box 10, Robert Duff, London, to Thomas Gordon, Edinburgh, 28 July 1802.

99 Ibid.

100 Box 2, Cairnbanno bundle, James Henderson to AG at Letterfourie, 15 February 1775.

${ }^{101}$ Box 2, Cairnbanno bundle, AG Letterfourie to JG, 15 January 1772.
} 
lands (although this did not come to fruition). ${ }^{102}$ Much of his energy once he succeeded to Letterfourie on his brother's death in 1790 was expended on trying to prove his title to the Baronetcy of Gordonstoun. ${ }^{103} \mathrm{He}$ would seem to have been much more concerned with landowning and its privileges than trade. Complaining about Alexander's lack of response to his letters on business matters in 1779 James sardonically remarked 'I hardly believe you would spare time from roaming in the fields, to read them with attention' ${ }^{104}$ This perhaps suggests that there was some truth in Robert's allegations that, in part at least, it was Alexander Gordon who was responsible for the check to their Madeira operations. The house recovered and continued to trade into the midnineteenth century, but that is beyond the scope of this article.

\section{Conclusion}

Cairns Craig has argued that if we wish to understand the role of Scots in the construction of the British empire 'we need histories of specific families and areas of the country. Even the grandest theories must be built upon such basic and particularist information. ${ }^{105}$ This article has provided one such history, with a particular focus on business practices. This focus reveals an intriguing network of connections which suggests that the relative neglect of connections between Scotland and Portugal in the eighteenth century merits further examination. Not far from Letterfourie, and completed four years later in 1776, stands the elegant house of Pitgaveny. This was built for James Brander, who made his fortune importing citrus fruits into London from Lisbon. ${ }^{106} \mathrm{~A}$ focus on such Scots who not only help to understand their contributions to the development of their home country, but would

\footnotetext{
102 Box 2, contracts and letters, AG Letterfourie to JG, 22 January 1783.

${ }^{103}$ MS3051/2/10/7 Papers of J M Bulloch relating to Gordons of Letterfourie

${ }^{104}$ Box 9, JG London to AG Letterfourie, 12 October 1779.

${ }^{105}$ Cairns Craig , 'Empire of Intellect: The Scottish Enlightenment and Intellectual Migrants' in John MacKenzie and T. M. Devine (eds), Scotland and the British Empire, (Oxford, 2011), 25.

${ }^{106}$ David Walker and Matthew Woodworth, Aberdeenshire: North and Moray, (London, 2015), 712.
} 
also counter the unfortunate conflation of 'British' with 'English' in Shaw's account of the merchant community on the Portuguese mainland in the eighteenth century. ${ }^{107}$

From the example of the House of Gordon and Duff the Scottish contribution might have been twofold. The European networks mobilized by Gordon to supply Madeiran needs for basic provisions encompassed, as we have seen, existing Scottish trading networks and merchant communities in the Baltic. Although the exporting activities of the house and other Scottish merchants were firmly embedded in the Atlantic trade with the West Indies and America, they depended on both commodities and financial services from Europe. For the latter, Amsterdam was a particularly important centre, drawing attention to the persistent links between Scotland and the Netherlands. ${ }^{108}$ The second Scottish contribution might have been thanks to levels of literacy and, in particular, attention to bookkeeping. Again this can be seen in the context of Scottish merchants receiving training in basic business practices in Dutch cities. '[I]had occasion in my Younger years to be bred at Holland in Merchant Accounts, Book-keeping and other parts of the Theorie of Merchandizing' recalled the minister of Glasgow Tron kirk in $1703 .{ }^{109}$ In this he was typical of many Scottish merchants.

Clark, of course, was a Presbyterian, Gordon a committed Roman Catholic. Both, however, emphasized the importance of detailed accounting. Gordon's comments about poor record keeping by his Portuguese managing partner could be read as a commitment to the virtues of order and record keeping (as well as a clear eyed view of their commercial utility). When Gordon arrived, he claimed, 'All the Books that appear'd were a confus'd Blotter or a sort of Waste Book in ye Portuguese language \& an Invoice Book wth some Accts of $\operatorname{Dr} \& \mathrm{Cr}$ in English by which it seem'd the

\footnotetext{
107 Shaw, Anglo-Portuguese Alliance

${ }^{108}$ Esther Mijers, Between Empires and cultures: Scots in New Netherland and New York, Journal of Scottish Historical Studies, 33(2), (2013), 163-195.

${ }^{109}$ James Clark, The Spiritual Merchant: or, the Art of Merchandizing Spiritualized, (Glasgow, 1703), vii.
} 
business of the house had not been extensive'. ${ }^{110}$ Given that Manuel da Costa Campos had an estate of his own and no mercantile training, that affairs were in a mess was perhaps not surprising. Gordon proceeded to use accounts to understand the state of the business and then was able to draw upon the literacy of his nephews, formed in the elementary education in their parish and then refined in London, to manage them. This management depended on careful attention to transaction recording and extensive correspondence. This correspondence was not limited to flows between Madeira and London, but also extended to India, where Patrick, in particular, was an assiduous correspondent. Given that the House of Gordon was an alliance, through ties of family, between Roman Catholics and Presbyterians we have to be wary of any facile deployment of notions of a 'Protestant Ethic'. At the local level, relationships of family and friendship overcame barriers of religion that might have been perceived as insurmountable at national centres. In this case, Roman Catholics like Gordon might have been able to draw on capabilities developed through a basically Protestant educational system. In other words, there were niches available for exploitation.

One of those niches, created in part by the strategic needs of the projection of British naval and military power, was Portugal. Portugal, and so Madeira, was deeply attached to Roman Catholicism, with the Inquisition having particular social weight. This could be threatening to Protestant merchants, who operated on sufferance and were subject to adverse actions, such as the dismissal of their evidence when they tried to pursue debts in Portuguese courts on the grounds that they were heretics. ${ }^{111}$ Protestants could not be buried on land on Madeira until 1761 and burial at sea was a deeply disturbing prospect for some. ${ }^{112}$ Roman Catholics like the Gordons did not face such challenges, which might have both made the island an attractive destination to men like James Gordon and enabled them to settle in. The Gordon brothers were from a family strongly committed

\footnotetext{
${ }^{110}$ Box 10 State of the case betwixt the late Mr Wm Halloran of London \& his partner Jas Gordon of Madeira.

${ }^{111}$ Shaw, Anglo-Portuguese Alliance, 82.

112 Hancock, Oceans of Wine, 29.
} 
to the survival of the Roman Catholic faith. Members of their extended family were prominent in the exiled Catholic hierarchy and the brothers would later be strong financial supporters of the chapel at Preshome on the borders of their Letterfourie estate, the first to be rebuilt in Scotland in the eighteenth century. ${ }^{113}$ In turn this adherence, alongside traditions of Jacobitism, might have pushed men like James Gordon out to trade. His family fortunes could only be repaired this way, given the civil liabilities under which Catholics laboured. Scotland had a long tradition of exporting people. Indeed, when Alexander sought to add to his Cairnbanno estate in 1784 the land offered for sale was the property of a returned Gothenburg merchant. ${ }^{114}$ This tradition of travelling to make money in the hope of eventual return meant that there was an extensive network of Scottish merchants, particularly in the Baltic, which could be used to develop the Madeira trade. As a destination Madeira was therefore not only attractive for its religious culture and its commercial opportunities, but because it lay as a key node in the expansion of shipping networks. This was of particular importance given the rush of Scots to the Caribbean. The opportunities offered by Grenada in particular were eagerly snapped up by Scots on the make, and in their wake followed flows of wine. $^{115}$

The success of the Gordons suggests that there were opportunities for Catholics in the construction of the British Empire. However, this does not shake the notion that Protestantism was a crucial factor in the development of British identity rather than refine it. The Gordons operated, it must be remembered, under the protection of the British Navy and traded to British possessions, first in the West Indies and America and then to India. They occupied a particular niche which helped support the development of networks and trade which posed no threat to a dominant Protestant

${ }^{113}$ Special Collections Centre, University of Aberdeen, MS3017/14/6 A short but distinct and faithful account of the building of the Roman Catholic chapel at Preshome, founded the year 1788 and finished 1790.

${ }^{114}$ Box 2, AG Letterfourie to JG London, 7 March 1784.

115 Devine, Scotland's Empire, 131; Douglas Hamilton, Scotland, the Caribbean and the Atlantic World 17501820, (Manchester, 2005), 49. 
construction of Britain. Once the military threat of Jacobitism had been decisively vanquished, men like James and Alexander Gordon could use their success in trade to become an accepted part of landed society while maintaining their adherence to the religion of their ancestors. 